IНТЕРМАРУМ: історія, політика, культура. - Вип. 7.

UDC 94 (477. 42) «1941-1943»

DOI $10.33287 / 112006$

Kovalchuk Ivan, $\mathrm{PhD}$ in History, Associate Professor of the Department of History of Ukraine, Zhytomyr Ivan Franko State University, ivankov1905@ rambler.ru ORCID: 0000-0002-2726-2866

\title{
THE FIGHTING BETWEEN UKRAINIAN NATIONALIST STRUCTURES AND SOVIET UNDERGROUND FORCES AND PARTISANS IN THE TERRITORY OF ZHYTOMYR REGION DURING THE NAZI OCCUPATION: REASONS, NATURE, THE EFFECTS (THE ATTEMPT OF CASE STUDY)
}

\section{Abstract}

The article deals with the issue of two totalitarian ideologies formation namely Communist and Nationalist in Ukraine. The emergence of these ideological doctrines in the Ukrainian lands occurred almost simultaneously, but their outreach across the population was accompanied by various factors and spread under different circumstances. The Communist doctrine suppoters seized and established themselves in power, and the nationalists tried to deprive them of power by means of the revolution. Starting from their formation it was determined the suppoters of these ideologies were in open confrontation and even used images of each other as a method of their own propaganda. This "propaganda and agitation war» between the Communists and Ukrainian nationalists took place during the 1920 s and 1930s, long before the outbreak of World War II.

The fighting between Soviet underground forces and partisans and Ukrainian nationalists is studied through the example of the Zhytomyr region territory during the Nazi occupation, involving a wide source base. As it is mentioned above, this fighting is know as a continuation and direct implementation of the previous propaganda and agitation war. Specific people, suppoters of hostile ideological and cultural positions moved and acted on predetermined by other trajectories. This 
INTERMARUM: history, policy, culture. - Issue 7.

circumstance attests the actual lack of personal choice of the people who has occured in that situation. The whole palette of interpersonal relationships was once again reduced to the paradigm of "personastrange», though often before, living in the same settlement or working together in the same institution, the «enemies» did not consider each other to be so.

It is found out that the fighting between Ukrainian nationalists and Soviet underground forces and partisans has caused additional suffering and losses to the Ukrainian people and has been beneficial to the Nazi occupation regime in the first place, since it weakened both sides. Taking into the consideration the state ideology, Ukrainians undoubtedly had the natural right to fight for their own state. Based solely on the humanist standpoint, both sides should take the blame for the violence in this confrontation.

Key words: the Bolsheviks, the Nazi occupation regime, OUN, the Soviet partisans, the Soviet underground forces, terror, the Ukrainian nationalists.

Introduction. The political history of mankind in the $20^{\text {th }}$ century was marked by the endorsement of two doctrines that embodied not only political ideas but also the ideological positions of hundreds of millions of people, representatives of Nationalism and Communism. According to the definition of the German philosopher, sociologist and economist Werner Zombart, these two ideologies are the poles between which history forms. The history of Ukraine in $20^{\text {th }}$ century represents the polarity, which demonstrates the bloody fighting between the suppoters of these political and ideological orientations.

Analysis of latest research studies and publications. The thematics of confrontation between the Soviet and Ukrainian nationalist components of the Resistance Movement during the Nazi occupation has been quite relevant for a long time, actually after the end of World War II. The Soviet and recent pro-Soviet historiography places the blame solely on the Ukrainian nationalists in this fighting, accusing them of servitude to the Nazi occupiers, of world imperialism and hatred of «popular Soviet power and established social justice». The former KGB veteran, member of the Union of Journalists of Ukraine Mykhailo Sheliug characterizes the activity of Ukrainian nationalists and their 
IНТЕРМАРУМ: історія, політика, культура. - Вип. 7.

opposition to the supporters of the Soviet ideology and power, for instance in Zhytomyr region, in a very negative way. In the late 1980s early 2000s, he published dozens of scholarly publications and articles in the local press, which covered the history of Ukrainian nationalists rather subjectively, unilaterally, and in a fragmentary way, but still did not deprive them of any partial factual credibility (Sheliug, 1994; Sheliug, 1996; Sheliug, 1997; Sheliug, 1999; Sheliug, 2000).

In contrast to the historical and ethnographic region of Volyn (Sukhykh, 2019), there is no comprehensive study of the fighting between the Soviet underground forces and partisans and Ukrainian nationalists during the Nazi occupation regime in the territory of Zhytomyr region (Sukhykh, 2019). Some factual evidence of the confrontation between the Ukrainian nationalist and Soviet components of the Resistance Movement during the Nazi occupation is available in the works of A. Kentii, A Rusnachenko, V. Kovalchuk, V. Zhyliuk, I. Patryliak and other authors (Kentii, 1999; Kentii, \& Lozytskyi, 2005; Kentii, 2008; Rusnachenko, 2002; Kovalchuk, (Comp.), 2007; Zhuliuk, 2008; Patryliak, 2012). However, according to these authors, the stated problems are not an independent subject of consideration and therefore are covered in the general context of the activities of the Ukrainian nationalist movement.

The aim of the research is a comprehensive study of the preconditions, the nature and the consequences of the confrontation of Ukrainian nationalist structures with Soviet underground forces and partisans in the territory of the Zhytomyr region during the Nazi occupation.

Presentation of the basic material of the research. During 19191920, the Ukrainian statehood, which was revived in March 1917, collapsed in the Dnieper region. The Soviet power of the Bolshevik Party established itself in this territory. Ideologically, Bolshevism is regarded as one of the branches of Marxism, which was formed as a political, philosophical, and economic doctrine at the end of the $19^{\text {th }}$ century (Kafarskyi, 2002, p. 232). Class struggle as one of the fundamental theses of Marxism-Leninism eventually led to the dictatorship of the proletariat. However, under the dictatorship of the proletariat, the dictatorship of the Bolshevik Party, or rather its top, was actually hidden. The Bolshevik leadership was clearly aware that terror 98 
INTERMARUM: history, policy, culture. - Issue 7.

was the means of asserting dictatorship. The need to use terror and violence to seize and retain power was theoretically justified by Lenin until the autumn in 1917 (Homizuri, 2005), and on September 5, 1918, a special decree «On Red Terror» was issued. The subsequent Bolshevik practice convincingly demonstrated that terror and violence were directed against not only the class and ideological enemies, the bourgeoisie and the exploiters, but against the workers and peasants who were accused of counter-revolutionary activity, «loss of class vigilance», etc. All these marked the beginning of the establishment of the totalitarian Soviet regime.

The young generation of activists of the Ukrainian national movement sought a new state ideology and answers to the question: how to achieve state independence? Dmytro Dontsov offered his own, quite simple, radical and effective answer. His ideas, which contained the foundations of creative violence, irrationalism, vitalism, dogmatism, anti-intellectualism, efficacy, recognition of the «law of struggle» and the «law of eternal rivalry of nations», became fundamental to the doctrine of Ukrainian nationalism.

He claimed that when Ukraine wanted to leave the state of the province, it had to find, in addition to the will to power, that great allencompassing idea, the idea of mastering a spiritual, economic and political nation. Such an idea might not be universal or social, but only a national idea aimed at the future and had the courage to conquer its world (Dontsov, 2001, p. 406).

From January 28 to February 3, 1929, the First Congress of the Organization of Ukrainian Nationalists (OUN) was held in one of the Vienna hotels. Congress elected a leader, Colonel of Sich Riflemen Yevhen Konovalets, approved the charter and adopted the basic provisions of the political, military, economic, cultural and ideological doctrine of the OUN. The main task of the nationalist movement was to gain independence for Ukrainian state. It was envisaged that during the period of national liberation (the first stage of state building), a dictatorship would be established in Ukraine, which would be created during the national revolution and act until the Ukrainian state was strengthened enough to repel possible external aggression (Muravskyi, 2006, p. 286). 
IНТЕРМАРУМ: історія, політика, культура. - Вип. 7.

Thus, the Ukrainian nationalists, like the Bolsheviks, considered the dictatorship the most effective means of retaining power initially. Accordingly, the members of OUN also used the terror actively against enemies who impeded the formation of the Ukrainian state. Such enemies were first the governments of Poland and the Soviet Union. In particular, on October 21, 1933, in Lviv, a member of the OUN, Mykola Lemyk, made an assassination of the secretary of the USSR Consulate Oleksiy Mailov (in fact, he was an employee of the Foreign Department of the United State Political Administration (OTPU) and his name was Andrii Pavlovych Mailov). The members of OUN executed this murder as a symbolic act of revenge for the 1932-1933 Holodomor in Soviet Ukraine (Kyrychuk, 2003, pp. 20-21). Such actions of the OUN members, as well as their desire to spread agency influence on the territory of Soviet Ukraine, seriously troubled the Soviet special services. It was decided to liquidate the head of Ukrainian nationalists E. Konovalets. On May 23, 1938, in the Dutch city of Rotterdam, NKVD agent Pavel Sudoplatov handed him a packet of explosives, disguised as a gift box from Ukraine. The explosion caused E. Konovalets to die on the spot (Patryliak, 2012, pp. 25-26). The loss of the leader eventually led to the split of the OUN into two separate organizations - led by Andriy Melnyk - OUN(M) and Stepan Bandera OUN(B).

Thus, already at the beginning of World War II, the Soviet authorities and Ukrainian nationalists were in an open confrontation aimed at mutual destruction.

During July 1941 the OUN(B) groups reached Berdychiv, Vinnytsia, Zhytomyr, Kryvyi Rih, Mykolaiv, Kherson. The report of the Soviet underground group in Zhytomyr highlighted the arrival of the Ukrainian nationalists. It stated that from the first days of the Germans' arrival in Zhytomyr on July 9, 1941, many Ukrainian supporters of Bandera came from Lviv and other western regions. The remains of local Petliura supporters and nationalists joined them (State Archives of Zhytomyr Region - SAZR, f. P-1376 , d. 1, f. 2, pp. 14-15). Soviet propaganda only described Ukrainian nationalists as servants of the Nazi occupiers. Korostyshiv underground forces indicated that the German henchmen were the Ukrainian nationalists, occupying all leading positions, conducting a total agitation against the Soviet state, 
INTERMARUM: history, policy, culture. - Issue 7.

praising the «new order» brought to Europe by the fascist barbarians (SAZR, f. P-1376, d. 1, f. 8, p. 20).

The report on the activities of the underground organization of Chudnivskyi district stated that, with their heads raised, Ukrainian nationalists began to persecute the Communists, occupy leading positions in the district and rural institutions, actively campaigning against the Soviet power, the Communist Party, and praising the invaders and their «leader» Bandera (SAZR, f. P-1376, d. 1, 38, p. 67).

Moreover, it was mentioned that those people would be remembered in the Zhytomyr region as traitors to their homeland and dedicated supporters of fascism. The hostile attitude of the OUN representatives to the supporters of the Communist ideology was particularly emphasized as they said that Nationalists directed the people to fight the remnants of the Communists and the Soviet assets, using radio and local press for this purpose (SAZR, f. P-1376, d. 1, f. 3, pp. 12-13).

Since September 1941, the Nazi punitive authorities had begun repression against members of the Ukrainian nationalist movement, first against Bandera supporters, and later against Melnyk ones. The Communist underground forces clarified this situationin in the following way: The Germans fought against the Ukrainian nationalists (Bandera supporters), persecuting and arresting them. The latter went underground, continuing their struggle against the Soviet state and against the Germans (SAZR, f. P-1376, d. 1, f. 3, p. 14). The mentioned above situation was advantageous to the Soviet side, because the Nazis directed their punitive measures against a rival on the Resistance Movement and eliminated it as the arrests of the nationalists began and the persecution of the Communists decreased (SAZR, f. P-1376, d. 1, f. 30, p. 47).

The military correspondent of the newspaper "Pravda" L. Korobkov informed in a note to the Central Committee of the Communist Party (the bolsheviks) of Ukraine that by January 1942 nationalists had understood what the true attitude of the Germans was to them. The Germans failed to use the nationalists to fight the Soviet partisans because they were unable to contact them (Central State Archives of Public Associations of Ukraine - CSAPAU, f. 62, d. 1, f. 220 , pp. 6-7). The latter information is particularly valuable because it 
ІНТЕРМАРУМ: історія, політика, культура. - Вип. 7.

refutes preliminary evidence of the Ukrainian nationalists «servitude» to the German invaiders.

During the initial period of their activities, the Ukrainian nationalists also paid special attention to the Soviet underground forces. A local resident and a member of the $\operatorname{OUN}(\mathrm{M})$, and since August 1, 1941, the chairman of the Zhytomyr Region Administration, Oleksander Yatseniuk, issued an oral order to a number of heads of district offices to supervise a former party-Soviet asset so that they would not engage in damage and other subversive activities (Archive of the Office of the Security Service of Ukraine in Zhytomyr region AOSSUZR, f. 5, d. 1, f. 8868, p. 46).

In general, the second half of 1941 clearly demonstrated the openly hostile attitude of the Soviet underground forces and Ukrainian nationalists towards each other in the occupied territory of the Zhytomyr region.

By this time, the open confrontation and bloodshed had taken place between the Soviet partisans and representatives of another direction of the Ukrainian national movement - detachments of the Ukrainian Insurgent Army «Polissia Sich» of Ataman Taras Bulba-Borovets. During the second half of 1941, this formation took control and «cleared» the territory of Olevskyi, part of the Slovechanskyi, Lugynskyi and Yemilchyinskyi districts of Zhytomyr region, part of the north-eastern districts of Rivne region and the south Belorussian Polissia region from the Red Army and Soviet partisans (Vengerska, V., Stelnykovych, S. (Eds.), 2017, pp. 442-443).

In early August 1941, a Soviet partisan detachment was formed in Olevshchyna. It was named after Chapaiev and was under the leadership of Lapshyn, and later the secretary of the Olevskyi district Committee of the Communist Party (the bolsheviks), Ivan Vozbranyi. The detachment was up to 260 people. It was stated that this detachment carried out combat operations in the villages of Suschany, Zhurzhevychi, Tepenytsia in Olevskyi district, during which 157 German soldiers and officers and 58 nationalists were killed (since the formation of Polissya Sich). In addition, on November 18, 1941, a group of nationalists of 80 people was defeated in the forest of Shebedykha tract by I. Vozbranyi's group (SAZR, f. P-1376, d. 1, f. 141, 4-6). 
INTERMARUM: history, policy, culture. - Issue 7.

The situation became much more complicated in the occupied territories in 1942. The Nazi civilian administration established an extremely violent occupation regime, one of the tasks of which was to combat the Soviet and nationalist movements. It should be noted that both parties used Nazi invaders whenever possible for repression and punitive actions against each other. Thus, in particular, the Soviet archival document states that Drebuschakov-«Sobchenko» was a nationalist. He betrayed the members of the underground forces namely Yevhenia Churkina, Bonifatii Cherko, Yurii Litvyniuk, Mykhailo Lazarenko, and Andrii Cherko, who were killed by German punishers in Yanushpole (SAZR, f. P-1376, d. 1, f. 14, p. 2).

A report from the German police stated that small arms units of the OUN(B) had appeared in the suburbs of Kamianets-Podilskyi and Zhytomyr since April 1942 (Kosyk, 2003, p. 63). A. Kentii points out that since the middle of the summer of 1942, the Bandera OUN began to prepare an armed struggle for the Ukrainian Independent Council of State (USSD) under favorable conditions (Kentii, 1999, p. 120).

The report on the underground group activity in village Turchynivka of the Chudnivskyi district stated that an underground group fought against Bandera. Peasants Petro Kryvotsiuk, Yosyp Razvod, Oleksandr Zadoienko were Bandera's suppoters and distributed postcards in the village, which a cyclist brought from Berdychiv every Saturday. The underground forces decided to intimidate Kryvotsiuk and Zadoienko's parents. After that, only the Bolshevik postcards were in the village (SAZR, f. P-1376, d. 1, f. 38, pp. 121-122).

In 1943, OUN(B) became the leader of the Ukrainian national underground forces, concentrating its activities around it. The secret service of Soviet partisans reported to the leadership of the USSR that on the territory of Western and Right-Bank Ukraine, the members of OUN strengthened their positions daily and started an armed struggle against the Germans for the establishment of independent Ukraine (Veselova, Dzobak, Dubyk, Serhiichuk, Kulchyt, Kulchyt, 2006, Kulchyt, 2006, pp. 8, 4). In fact, at the same time, there was an intensification of the Soviet partisans activities, whose purpose, among other things, was to counteract and fight against the Ukrainian nationalists. The confrontation between the supporters of Communism and Ukrainian nationalism ideology entered the final phase. It was the 
IНТЕРМАРУМ: історія, політика, культура. - Вип. 7.

period which was marked by the fiercest struggle, the common bloodshed and the desire to oust and physically destroy one another.

The Nazi invaders, in accordance with the principle of «divide and conquer» in every way intensified the fighting between the Ukrainian nationalists and the Soviet underground forces and partisans. Thus, the Ukrainian nationalists themselves noted that in the Andrushivskyi district it was noticed about 10 cases when the German Gestapo operated under the guise of partisans, who murmured Several of the Ukrainian nationalists and left their bodies in the forest (SARR, f. R-30, d. 2, f. 41, p. 16).

A detailed description of the activities of the Soviet partisans of the Olevskyi district is given in the «Report on the combat activity of the Olevskyi partisan unit of the formation of Comrade Kovpak (commander Efymchuk)»(SAZR, f. P-1376, d. 1, f. 140, p. 136). Among other things, part of the partisans' activities was determined by the fighting with Ukrainian-German nationalists (a term actively used in the Soviet propaganda). Specifically, it states that Olevskyi district was unreliable in nationalist sentiment. In almost every village there were representatives of nationalist groups, with the appearance of partisans, some of them went to the southern part of the district, some to Olevsk, some to the village Dert in the Rivne region and the remaining ones were captured and killed by the partisans (SAZR, f. P-1376, d. 1, f. 140, p. 12). The document then provides a detailed account of the location and number of killed Ukrainian nationalists. It should be noted that the Soviet archival documents are rather uncertain sources in terms of the reliability of the individual factual data. However, taking into consideration the general trend, this source demonstrates it.

Nationalists of local orign were exterminated because the local partisans knew them personally and those who were non-native remained elusive.

In 1943, from February 20 to March 2, in the village Yurove and surrounding villages, three nationalist agents were killed. April, 17, 1943 a group under the command of Commissioner Budzylovskyi killed 5 nationalists in the village Sushchany. April, 21, 1943 the secret service department under the command of M. Stepanka captured and killed one nationalist agent in the village Zhurzhevychi. May 14, 1943, a group under the command of $\mathrm{T}$. Tolakh, who persecuted the nationalists in the 
INTERMARUM: history, policy, culture. - Issue 7.

village Radorobel, killed one nationalist. May 30, 1943, a group killed 6 nationalists on the way to the village Hniine. June, 2, 1943 a group killed 4 nationalists in the forest near the village Tomashhorod (Rivne region) as a result of the battle (SAZR, f. P-1376, d. 1, f. 140, pp. 5557).

In the summer of 1943, the leaders of the OUN underground forces of the Pulynskyi district, Volodymyr Kharko and Elena Zborovska, hid in the village Ivanovych at Olha Vlasenko and Domna Kryzova. Subsequently, O. Vlasenko was killed by the Soviet partisans for cooperation with the members of OUN (AOSSUZR, f. 6, d. 1, f. 28871, pp. 18-20).

In June - July, 1943, the second and third divisions of the UPA «Tiutiunnyk» group under the command of «Vereshchak» (Fedir Vorobets) (Kentii, \& Lozytskyi, 2005, p. 377) reached Andrushivskyi and Korostenskyi districs of Zhytomyr region and Fastivskyi district of Kyiv region. They had clashes with the Soviet partisans, in particular a major battle took place near the village Zablotska (more likely, village Zabolot of Radomyshl district) At the end of July 1943 the rebels were in the forests of Chopovytskyi and Malynskyi districts, where another battle with the partisans occurred. This time it was with the detachment of Lieutenant Hrechov, a local miner and saboteur who died as a result of the battle (Dashkevych, (Comp.), 1996, p. 534). During their departure, the rebels conducted several small battles with the Soviet partisans, in particular near the villages Katerynivka and Krasylivka, Yemilchynskyi and Yarunskyi districts (Vovk, \& Pavlenko (Comps.), 1999, pp. 640-641). In the documents of the Novohrad-Volynskyi underground forces, thare is available information about the dead in the confrontation with the groups of Kyrylo Yushchenko and Fedir Lopatiuk (SAZR, f. R-1376, d. 1, f. 89, pp. 49-50) and the partisans Oleksander Zahryvyi and Feodosii Tymoschuk in the village Krasylivka (SAZR, f. P-1376, d. 1, f. 1, p. 63).

The report on July 29, 1943 informed about the raid of hundreds of «Hordienko» from the UPA «Bohun» group in the southern part of Zhytomyr region. Having entered the territory of Zhytomyr region from the side of Rovenshchyna, on July 17, 1943, near the villages Kamianka and Zholobne, Yarunskyi district they fought twice: the first time with the Soviet partisans and the second with the German troops. On July 26 
ІНТЕРМАРУМ: історія, політика, культура. - Вип. 7.

in the villageVyshnevychi, Radomyshlskyi district, near the Teteriv River they attacked a detachment of the Soviet partisans (CSASBPMU, f. 3833, d. 1, f. 112, p. 12).

Separate military units of Ukrainian nationalists were formed in the territory of the Zhytomyr region. Thus, on August 8, 1943, a clash of the UPA led by «Zhuk» with the Soviet sabotage-subversive group of «Pauk» (Ivan Bohorad), which operated on the territory of Andrushivskyi and Vchoraishenskyi districts (SAZR, f. P-1376, d. 1, f. 151, pp. 22, 159-161). And on August 29 and September 1, 1943, this group of partisans attacked a large and well-armed detachment of Bandera's supporters in the village Zarubyntsi, Andrushivskyi district. In the result of this battle the commander of Ukrainian nationalists group «Bohdan» was killed (SAZR, f. P-1376, d. 1, f. 43, p. 83).

The Ukrainian insurgents applied the same methods to the Soviet underground forces and partisans. In August 1943, the fighters of «Zhuk» group organized an escape from the Berdychiv prison of the Colonel Dovhopolov, hoping to apply his knowledge of military affairs to his struggle, but during the Soviet agitation among the fighters of the group he was executed (AOSSUZR, f. 5. 1, f. 32527, p. 8).

The UPA document «On Ukraine. The Socio-Political Survey of September 1943» on the territory of the OUN Andrushivskiy district, which included 4-5 neighborhoods, reported in general about 6 major fights with the Bolshevik partisans and 2 conflicts with the German police (SARR , f. R-30, d. 2, f. 41, p.15).

In October 1943, the head of the local insurgency of the UPA «Zhuk» shot and killed the former head of the collective farm V. Tymoschuk. Also, in October 1943, the firing of the residents of the village Nykonivka, Berdychiv district, namely Matviichuk, Kashchuk, Kozachenko, and Muzychuk was performed by the members of OUN in the Kodenschyna forest (Sheliug, 1994, p. 257). The OUN(B) member Feodosii Hlob gave the names of five former Soviet activists from the village Synhaivka in the same district, who were later killed, to the local UPA militia. (AOSSUZR, f. 6, d. 1, f. 5218, p. 75)

In addition to physical liquidation of their enemies, the parties of the conflict often resorted to intimidation and violence against civilians who supported or assisted the opposite party, spreading hyperbolized data, and often outright misinformation. Ukrainian nationalists reported 
INTERMARUM: history, policy, culture. - Issue 7.

there were often cases of women being raped (by the Bolshevik partisans)? For examples in the villages Mynkivka, Korenivka of Potiivskyi district of Zhytomyr region. They took away everything they noticed (SARR, f. R-30, d. 2, f. 41, p. 17). On the other hand, in order to weaken the movement of Bandera suppoters in the area of their activity, the Soviet partisans resorted to the destruction of their supporters from the local population (SAZR, f. P-1376, d. 1, f. 43, p. 58, 106).

In October 1943 in the village Verkhivnia of Vcheraishenskyi district, four Soviet partisans were killed by local Ukrainian nationalists. In November 1943, the nationalists of the villages Verkhoivnia and Bystryk carried out diversions and set fire to the public buildings. The purpose of the sabotage was to shift the blame on the Soviet partisans and thereby provoke the Nazis punitive actions against them (AOSSUZR, f. 5, d. 1, f. 4167, p. 25-26). The Soviet partisans, on their part, carried out retaliatory actions. For instance, in December 1943 and January 1944, they killed the local members of OUN namely Stepan Volynets, Semen Hetman and Oleksander Yurchenko. The report of the Ruzhyn partisan detachment states that in total about 80 Ukrainian nationalists and a leader of the OUN (SAZR, f. P-1376, d. 1, f. 144, p. 2 ) were killed. This is most certainly an exaggeration, since so many Ukrainian nationalists simply did not physically exist in the mentioned territory.

According to the memoirs of Maxym Skorupskyi, at the beginning of October 1943, a kurin of «Kvartyrenko» (sotnias of «Lev", «Burevii», «Skyrda») of the Ukrainian Insurgent Army «Zahrava» group and two sotnias of «Nehus» and «Maks» of the group «Bohun», who formed the second kurin, set off a four-week raid. The general campaign was conducted by «Vereshchak» (Skorupskyi, 1992, pp. 171174). During the raid, these kurins had armed conflicts with the Soviet partisans almost every day. Initially, the OUN Security Service executed the partisans prisoners, and subsequently, by order of the officers' council, all the prisoners, regardless of nationality, were disarmed and released. However, this provision did not apply to commissioners and members of the CPSU(b) (Skorupskyi, 1992, pp. 174-175).

The extra front of the fight was burdensome for both of its participants. Therefore, during the second half of 1943, there were negotiations between some representatives of Ukrainian nationalists and 
ІНТЕРМАРУМ: історія, політика, культура. - Вип. 7.

commissioners of partisan alliances of Sydir Kovpak, Oleksander Saburov, Oleksii Fedorov, and Yakov Shkriabach (including in the territory of the Zhytomyr region). Negotiations regarded the neutrality of both parties towards each other during their fighting against the German occupiers. However, these negotiations had no real practical implications (Kentii, \& Lozytskyi, 2005, p. 387).

In November-December 1943 and in January 1944 the territory of Zhytomyr region became the scene of protracted and bloody battles between the Wehrmacht and the Red Army. In these circumstances, the fighting between the Ukrainian nationalists and the Soviet underground forces and the partisans took a different turn as both sides prepared for the return of the Soviet power. However, each of these parties had different expectations about it, the former perceived the Soviet authorities as a new occupier, the latter as their liberator.

Conclusions and perspectives. The confrontation between Ukrainian nationalists and Communist ideologists began on the eve of World War II. However, it became a truly uncompromising and ruthless fighting during the Nazi occupation of Ukraine. As a result, it turned out to be the internal front for the people of Ukraine, caused loss and suffering and reduced the chances of survival firstly for the local residents, burdened by the cruel Nazi occupation regime. Unfortunately, the territory of Zhytomyr region had not become a positive exception in this fighting, but only once again demonstrated a general trend. This article deals with the most illustrative and large-scale cases of the confrontation between the supporters of the Ukrainian nationalist and Soviet-communist ideologies in the territory of Zhytomyr region. It is still difficult to determine at least the estimated death toll on both sides. We can testify that the count reaches hundreds, and perhaps thousands, killed in this fight. Further study of this issue will contribute to a better understanding of the phenomenon of ideological confrontation in a particular territory and in general in Ukraine.

\section{BIBLIOGRAPHY}

Archive of the Office of the Security Service of Ukraine in Zhytomyr region - AOSSUZR, fund 5,description 1, file 4167, 118 pages. 
INTERMARUM: history, policy, culture. - Issue 7.

Archive of the Office of the Security Service of Ukraine in Zhytomyr region - AOSSUZR, fund 5, description 1, file 8868, 175 pages.

Archive of the Office of the Security Service of Ukraine in Zhytomyr region - AOSSUZR, fund 5, description 1, file 28871, 137 pages.

Archive of the Office of the Security Service of Ukraine in Zhytomyr region - AOSSUZR, fund 5, description 1, file 32527, 78 pages.

Archive of the Office of the Security Service of Ukraine in Zhytomyr region - AOSSUZR, fund 6, description 1, file 5218, vol. 1,205 pages.

Archive of the Office of the Security Service of Ukraine in Zhytomyr region - AOSSUZR, fund 6, description 1, file 28871, 137 pages.

Central State Archives of Public Associations of Ukraine CSAPAU, fund 62, description 1, file 220, 125 pages.

Central State Archives of the Supreme Bodies of Power and Management of Ukraine - CSASBPMU, fund 3833, description 1, file 112, 43 pages.

Dashkevych,Ya. (Comp.). (1996). A history of the Ukrainian army. Lviv: Svit, 840 p. [in Ukrainian].

Dontsov, D. (2001). Works.Volume 1.Geopolitical and ideological works. Lviv: Calvary, 488 p. [in Ukrainian].

Homizuri G. (2005).V. I. Lenin on terror (theory and practice) (Quotes without comment).URL: http://ru.scribd.com/doc/66462468/ (Accessed 25.11.2018) [in Russian].

Kafarskyi, V. (2002). The communism and the Ukrainian national liberation movement. Ivano-Frankivsk: Plai, 832 p. [in Ukrainian].

Kentii, A. (2008). The armed action of Ukrainian nationalists. 1920-1956. Historical and archival essays.Ukrainian Insurgent Army and Armed Underground Organization of Ukrainian Nationalists. 1942-1956. (Vol. 2.). Kyiv: Derzhavnyj komitet arkhiviv Ukrayiny, 416 p. [in Ukrainian].

Kentii, A. (1999). Essays on the History of the Organization of Ukrainian Nationalists in 1941-1942. Kyiv: Institute of History of Ukraine, NAS of Ukraine, 201 p.[in Ukrainian]. 
IНТЕРМАРУМ: історія, політика, культура. - Вип. 7.

Kentii, A., \& Lozytskyi, V. (2005). The War without mercy and clemency. Partisan Front at the rear of the Wehrmacht in Ukraine 1941-1944. Kyiv: Geneza, 408 p. [in Ukrainian].

Kosyk, V. (2003). UPA in German documents. Ukrainian Liberation Movement, 1, 57-86. [in Ukrainian].

Kovalchuk, V. (Comp.). (2007). The network of UPA and underground in the territory of the military units "Zahrava», «Turiv», «Bohun» in August of 1942-December of 1943. Kyiv; Toronto: Litopys UPA, 845 p. [in Ukrainian].

Kyrychuk, Yu. (2003).Ukrainian national movement of the 4050's of the 20 $0^{\text {th }}$ Century: ideology and practice.. Lviv: Dobra sprava, 464 p. [in Ukrainian].

Muravskyi, V. (Comp.) (2006). 1929 Congress of Ukrainian Nationalists: documents and materials. NAS of Ukraine; LNL them. V. Stefanyk; Liberation Movement Research Center. Lviv, 420 p. [in Ukrainian].

Patryliak, I. (2012). "Get up and fight! Listen and Believe...»: Ukrainian nationalist underground and insurgent movement (19391960). Lviv: Chasopys, 592 p. [in Ukrainian].

Rusnachenko, A. (2002). People upset: national liberation movement in Ukraine and national resistance movements in Belarus, Lithuania, Latvia, Estonia in the 1940s - 50s. Kiev: Pulsary University Publishing House, 519 p. [in Ukrainian].

Sheliug, M. (1994).The struggle of Zhytomyr region state security employees against German occupants and their servants. Abstracts of Papers '94: The residents of Zhytomyr on the fronts of the Great Patriotic War. Memories of veterans. 1941-1945. (pp. 252-264). Zhytomyr. [in Ukrainian].

Sheliug, M. (1996). You don't hide the truth!: a collection of documentary stories about OUN-UPA activities. Zhytomyr: CPJF, 48 p. [in Ukrainian].

Sheliug, M. (1997). OUN: A History Pages (in questions and answers). Zhytomyr: Newspaper's publishing «Zhytomyr», 48 p. [in Ukrainian].

Sheliug, M. (1999). They carried the trouble or legal assessment of the OUN-UPA's activities. Zhytomyr: Newspaper's publishing «Zhytomyr», 60 p. [in Ukrainian]. 
INTERMARUM: history, policy, culture. - Issue 7.

Sheliug, M. (2000). «True eye to the stake» or UPA «East» in Zhytomyr region. Abstracts of Papers '2000: The young patriots of Zhytomyr region in the Great Patriotic War.(pp. $37-44)$. Zhytomyr. [in Ukrainian].

Skorupskyi, M. (1992). Wherever you will: (memories of Maxim Skorupskoho-Max). Kyiv: Cossacks, 352 p. [in Ukrainian].

State Archives of Rivne region - SARR, fund R-30, description 2, file 41, 17 pages.

State Archives of Zhytomyr region - SAZR, fund P-1376, description 1, file 1, 133 pages.

State Archives of Zhytomyr region - SAZR, fund P-1376, description 1 , file 2, 144 pages.

State Archives of Zhytomyr region - SAZR, fund P-1376, description 1, file 3, 118 pages.

State Archives of Zhytomyr region - SAZR, fund P-1376, description 1 , file 8,173 pages.

State Archives of Zhytomyr region - SAZR, fund P-1376, description 1, file 14, 35 pages.

State Archives of Zhytomyr region - SAZR, fund P-1376, description 1, file 30, 66 pages.

State Archives of Zhytomyr region - SAZR, fund P-1376, description 1, file 38, 252 pages.

State Archives of Zhytomyr region - SAZR, fund P-1376, description 1, file 43, 166 pages.

State Archives of Zhytomyr region - SAZR, fund P-1376, description 1, file 89, 88 pages.

State Archives of Zhytomyr region - SAZR, fund P-1376, description 1, file 140, 136 pages.

State Archives of Zhytomyr region - SAZR, fund P-1376, description 1, file 141, 17 pages.

State Archives of Zhytomyr region - SAZR, fund P-1376, description 1, file 144, 90 pages.

State Archives of Zhytomyr region - SAZR, fund P-1376, description 1, file 151, 259 pages.

Sukhykh, A. (2019). Confrontation between the Soviet partisans and the Ukrainian rebel-underground movement in Volyn during the 
IНТЕРМАРУМ: історія, політика, культура. - Вип. 7.

German occupation (1941 - 1944) (Extended abstract of Candidate'sth esis). Ostroh. [in Ukrainian].

Vengerska, V., Stelnykovych, S. (Eds.). (2017). Essays on the history of Zhytomyr region in the first half of the twentieth century. Zhytomyr: «Polissia», 552 p. [in Ukrainian].

Veselova, O., Dzobak, V., Dubyk, M., Serhiichuk, V. \& Kulchyt skyi, S. (Comps.). (2006). OUN and UPA in 1943: documents. Kyiv: Institute of History of Ukraine, NAS of Ukraine, 347 p. [in Ukrainian].

Vovk, O., \& Pavlenko, I. (Comps.).(1999). Chronicle of the UPA. New series. (Vol. 2): The Volhynia and Polesia: UPA and underground forces 1943-1944: Documents and materials. Kyiv; Toronto: Litopys UPA, 724 p. [in Ukrainian].

Zhuliuk, V. (2008). Th eactivity of the OUN and UPA in Zhytomyr region in 1941-1955. Rivne: Volynski oberehy, 308 p. [in Ukrainian].

\section{Ковальчук Іван. БОРОТЬБА МІЖ УКРАЇНСЬКИМИ НАЦІОНАЛІСТАМИ ТА РАДЯНСЬКИМИ ПЦДПІЛЬНИКАМИ І ПАРТИЗАНАМИ НА ТЕРИТОРІЇ ЖИТОМИРСЬКОЇ ОБЛАСТІ У ПЕРІОД НАЦИСТСЬКОЇ ОКУПАЦӤ: ПРИЧИНИ, ХАРАКТЕР, НАСЛІДКИ (СПРОБА ДЖЕРЕЛЬНОГО АНАЛІЗУ) Анотація}

У статті досліджується питання становлення в Україні двох тоталітарних ідеологій - комуністичної та націоналістичної. Зародження цих ідеологічних доктрин на украӥнських землях відбувалося майже одночасно, однак їх охоплення свідомістю населення супроводжувалося різними чинниками та розгорталося за відмінних обставин - носї комуністичної доктрини захопили та утвердилися при владі, націоналісти ж намагалися позбавити їх влади шляхом майбутньої національної револючії. Визначено, щзо із моменту свого зародження носії вказаних ідеологій перебували у відкритому протистоянні та навіть використовували образи один одного як метод власної пропаганди. Ця «пропагандистськоагітаційна війна» між комуністами та украӥнськими націоналістами розгорнулася упродовж 1920-1930-х рр., ще задовго до початку Другої світової війни.

На прикладі конкретного регіону (території Житомирської області) у роки нацистської окупачії, залучаючи широку 
INTERMARUM: history, policy, culture. - Issue 7.

джерельну базу, простежено боротьбу між радянськими підпільниками $і$ партизанами та украӥнськими націоналістами. 3'ясовано, щз ия боротьба стала продовженням $і$ безпосереднім дієвим втіленням попередньої «пропагандистсько-агітаційної війни». Конкретні особи - носії ворожих ідеологічних $i$ світоглядних позичій рухались $і$ діяли за наперед визначеними кимось іншим траєкторіям. Вказана обставина засвідчує фактичну відсутність особистого вибору у людей, щзо опинилися у тій ситуації. Вся палітра міжлюдських взаємин вкотре була зведена до парадигми «свій - чужий», притому щуо раніме, мешкаючи у межах одного населеного пункту, чи спільно прачюючи в якійсь установі, «вороги» аж ніяк вважали однин одного такими.

Встановлено, щзо боротьба міжрадянськими підпільниками та партизанами й українськими націоналістами завдала додаткових страждань і втрат українському народу та була вигідна перш за все нацистському окупаційному режиму, оскільки ослаблювала обидві ворожі йому сторони. Враховуючи державницьку ідеологію, безперечно, украйнці мали природнє право вести боротьбу за власну державу. Виходячи виключно з гуманістичних позицій, провину за насильство та жорстокість у изьому протистоянні все ж варто покладати на дві сторони.

Ключові слова: більшовики, нацистська окупація, ОУН, радянські партизани, радянські підпільники, терор, українські начіоналісти.

Kowalczuk Iwan. WALKA MIĘDZY UKRAIŃSKIMI NACJONALISTAMI A RADZIECKIM PODZIEMIEM I PARTYZANTAMI NA TERYTORIUM ŻYTOMIERSKIEGO OBWODU W OKRESIE OKUPACJI NAZISTOWSKIEJ: PRZYCZYNY, CHARAKTER, KONSEKWENCJE (PRÓBA ANALIZY ŹRÓDEL)

\section{Streszczenie}

Artykut analizuje kwestię zapoczątkowania na Ukrainie dwóch ideologii totalitarnych - komunistycznej i nacjonalistycznej. Pojawienie sie tych ideologicznych doktryn na ziemiach ukrainskich nastapito prawie jednocześnie, ale ich osiagnięciu świadomościa ludności 
IНТЕРМАРУМ: історія, політика, культура. - Вип. 7.

towarzyszyty różne czynniki $i$ rozwijały się one $w$ różnych okolicznościach. Posiadacze doktryny komunistycznej zdobyli władze $i$ ustanowili się u niej, a nacjonaliści próbowali pozbawić ich władzy przez rewolucję. Ustalono, że od momentu ich początku nosiciele tych ideologii byli w jawnej konfrontacji, a nawet wykorzystywali wzajemne obrazy jako metode własnej propagandy. Ta «agitacyjnopropagandowa wojna» między komunistami a nacjonalistami ukraińskimi miała miejsce $w$ latach 1920-1930, na dtugo przed wybuchem drugiej wojny światowej.

Biorac za przykład konkretny region (terytorium Żytomierskiego obwodu) $i$ analizujac szeroka baze źródłowa, podczas okupacji nazistowskiej widać walkę między podziemiem sowieckim i partyzantami a ukraińskimi nacjonalistami. Jasne stato się, że walka ta była kontynuacja $i$ bezpośrednia realizacja poprzedniej «agitacyjnopropagandowej wojny». Określone osoby - nosiciele wrogich pozycji ideologicznych $i$ światopogladowych poruszali się $i$ działali zgodnie $z$ ustalonymi przez kogoś trajektoriami. Okoliczność ta świadczy o faktycznym braku osobistego wyboru ludzi, którzy byli w tamtej sytuacji. Cała paleta relacji międzyludzkich po raz kolejny została skierowana do paradygmatu «swój-nieswój», ponieważ wcześniej, żyjąc w granicach jednej osady lub pracując razem $w$ instytucji, «wrogowie» nie uważali sie wzajemnie wrogami.

Stwierdzono, ̇̇e walka między sowieckim podziemiem $i$ partyzantami a ukraińskimi nacjonalistami spowodowata dodatkowe cierpienia $i$ straty dla narodu ukraińskiego $i$ byta korzystna przede wszystkim dla nazistowskiego reżimu okupacyjnego, ponieważ osłabiła obie strony. Biorac pod uwage ideologię państwowa, Ukraincy niewatpliwie mieli naturalne prawo do walki o własne państwo. Z czysto humanistycznego punktu widzenia winę za przemoc i okrucieństwo w tej konfrontacji warto położyć na obie strony.

Stowa kluczowe: bolszewicy, okupacja nazistowska, OUN, radzieccy partyzanci, radzieckie podziemie, terror, ukraińscy nacjonaliści.

The article was received 10.03.2019

Article recommended for publishing 11.28.2019 